\title{
Stratocumulus cloud thickening beneath layers of absorbing smoke aerosol
}

\author{
E. M. Wilcox \\ Desert Research Institute, Reno, Nevada, USA
}

Received: 26 July 2010 - Published in Atmos. Chem. Phys. Discuss.: 9 August 2010

Revised: 20 November 2010 - Accepted: 24 November 2010 - Published: 10 December 2010

\begin{abstract}
Marine stratocumulus cloud properties, and the free-tropospheric environment above them, are examined in NASA A-Train satellite data for cases where smoke from seasonal burning of the West African savannah overlay the persistent southeast Atlantic stratocumulus cloud deck. CALIPSO space-borne lidar observations show that features identified as layers of aerosol occur predominantly between $2 \mathrm{~km}$ and $4 \mathrm{~km}$. Layers identified as cloud features occur predominantly below $1.5 \mathrm{~km}$ altitude and beneath the layer of elevated smoke aerosol. The diurnal mean shortwave heating rates attributable to the absorption of solar energy in the aerosol layer is nearly $1.5 \mathrm{~K} \mathrm{~d}^{-1}$ for an aerosol optical thickness value of 1 , and increases to $1.8 \mathrm{~K} \mathrm{~d}^{-1}$ when the smoke resides above clouds owing to the additional component of upward solar radiation reflected by the cloud. As a consequence of this heating, the $700 \mathrm{hPa}$ air temperature above the cloud deck is warmer by approximately $1 \mathrm{~K}$ on average for cases where smoke is present above the cloud compared to cases without smoke above cloud. The warmer conditions in the free-troposphere above the cloud during smoke events coincide with cloud liquid water path values that are greater by $20 \mathrm{~g} \mathrm{~m}^{-2}$ and cloud tops that are lower for overcast conditions compared to periods with low amounts of smoke. The observed thickening and subsidence of the cloud layer are consistent with published results of large-eddy simulations showing that solar absorption by smoke above stratocumulus clouds increases the buoyancy of free-tropospheric air above the temperature inversion capping the boundary layer. Increased buoyancy inhibits the entrainment of dry air through the cloud-top, thereby helping to preserve humidity and cloud cover in the boundary layer. The direct radiative effect of absorbing aerosols residing over a bright cloud deck is a positive radiative forcing (warming) at the top of the at-
\end{abstract}

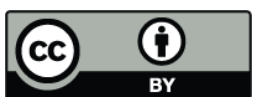

Correspondence to: E. M. Wilcox (eric.wilcox@dri.edu) mosphere. However, the greater liquid water path for cases of smoke overlaying cloud contributes an additional negative semi-direct radiative forcing (cooling) of climate in locations such as the southeast Atlantic Ocean owing to the enhanced albedo of the thicker cloud.

\section{Introduction}

The impact of aerosols upon the climate of Earth has received intense scrutiny because of the uncertain role aerosols play in present-day anthropogenic radiative forcing of climate (IPCC, 2007), and the prospect for large present and future impacts of aerosol forcing on regional and global hydrological cycles (e.g. Ramanathan et al., 2001; Liepert et al., 2004). The radiative forcing by aerosols arises both through the direct scattering and absorption of solar radiation by aerosol particles, as well as the modification of clouds by aerosols, which can impact the transmission of solar and infrared radiation through the cloud layer.

In cases where absorbing aerosols (e.g. smoke and soot) coincide with clouds in the same column, the radiative heating of the troposphere by aerosol solar absorption may modify the thickness and coverage of the cloud layer depending on the radiative properties of the aerosol, the meteorology driving the cloud dynamics, and the vertical distribution of the aerosol relative to the cloud in the column. This socalled semi-direct effect of aerosols (Hansen et al., 1997) is often assumed to yield a positive radiative forcing (warming) of climate. When the absorbing aerosol mixes with shallow broken clouds in the same layer, the radiative heating of the layer by solar absorption can reduce the cloud cover (Ackerman et al., 2000), increasing the absorption of solar radiation at the surface and leading to a net positive radiative forcing.

This study examines the consequences for marine stratocumulus clouds of absorbing aerosol residing above the cloud-topped marine boundary layer. Seasonal burning of the

Published by Copernicus Publications on behalf of the European Geosciences Union. 
southwestern African Savannah produces episodic plumes of dark smoke over the southeast Atlantic Ocean. Beneath the elevated layer of smoke is a persistent deck of bright marine stratocumulus cloud. Field measurements have verified that the smoke is substantially absorbing in the ultraviolet (UV) and visible wavelengths (Haywood et al., 2004), meaning that both the downward incident solar radiation from above, and the upward reflected solar radiation from the cloud-top below are substantially attenuated as solar energy is deposited in the smoke layer. The persistence of shallow stratocumulus beneath deep plumes of absorbing smoke aerosol over the southeast Atlantic Ocean during the dry season provides a natural laboratory for testing the response of stratocumulus clouds to overlaying absorbing aerosol.

The geographical distribution of smoke from African Savannah burning, as well as the microphysical and radiative properties of the smoke, were among the topics of study of the Southern African Regional Science Initiative (SAFARI) 2000 field campaign. During sampling offshore of West Africa, smoke was typically observed in layers that were vertically separated from stratocumulus clouds below (Hobbs, 2002; McGill et al., 2003). These observations imply that direct microphysical interaction between the aerosols and stratocumulus clouds is often inhibited by the strong temperature inversion above the cloud layer.

In large-eddy simulations of California stratocumulus cloud cases, Johnson et al. (2004) find that when the absorbing aerosol layer occurs in the boundary layer, the cloud liquid water path (LWP) decreases, yielding a positive semidirect radiative forcing. However, when the aerosol layer occurs entirely above the boundary layer the temperature inversion above the boundary layer is enhanced, LWP increases, and the semi-direct radiative forcing is negative (a cooling). Evidence for both increases and decreases in cloud fraction associated with biomass burning aerosols offshore of California were reported by Brioude et al. (2009) depending on whether simulated smoke in a chemical transport model had mixed into the boundary layer or not. In this study we confirm the results of the Johnson et al. (2004) study for overcast decks of cloud to the presence of smoke above the boundary layer with an empirical analysis of a suite of NASA A-Train satellite observations and complementary radiative transfer calculations. The observations confirm that the smoke layer is often distinct from the cloud layer below and that a positive correlation of smoke loading and cloud liquid water path can be explained by warming of the cloud-capping temperature inversion attributable to solar absorption by smoke.

\section{Data and methods}

A combination of satellite observations and a numerical radiative transfer model are used to establish a link between absorbing smoke aerosol and a thickening of marine stratocumulus cloud beneath the smoke layer. Several of the satellite data sets employed, and the processing techniques applied to the satellite data, are similar to those described in Wilcox et al. (2009). Essential details are described below. Additional details and discussion can be found in Wilcox et al. (2009).

The vertical profile of smoke and cloud is determined using the aerosol and cloud feature mask derived from CALIOP lidar backscatter measurements from the CALIPSO satellite (Liu et al., 2009; Winker et al., 2009). A histogram of aerosol and cloud layer heights is used to construct a canonical profile for cases of coincident smoke aerosol overlaying cloud for input into the plane-parallel radiative transfer model of Chou (1992). Sensitivity studies are performed with the model to estimate the tropospheric heating rate for varying values of smoke aerosol optical depth (AOD) and cloud fraction.

The signature of tropospheric heating by absorbing smoke aerosol is observed in Atmospheric Infrared Sounder (AIRS) satellite tropospheric temperature products based on the AIRS/AMSU retrieval algorithm (Susskind et al., 2006). In order to properly interpret the AIRS temperatures, samples are sorted according coincident observations of sea surface temperature (SST) from the Advanced Microwave Scanning Radiometer-EOS (AMSR-E) sensor (Wentz and Meissner, 2000; Wentz et al., 2003) and the aerosol index (AI) derived from the Ozone Monitoring Instrument (OMI) instrument (Herman et al., 1997; Torres et al., 2007). The AIRS and AMSR-E instruments are on the Aqua satellite and the OMI instrument is on the Aura satellite. The Aura satellite follows the Aqua satellite in the same orbit approximately 15 minutes behind. All data are taken from the daytime pass of the A-Train satellite constellation (approximately 1:30 p.m. local time).

The response of the clouds to tropospheric heating is determined using AMSR-E observations of cloud LWP (Wentz, 1997; Wentz and Spencer, 1998). We rely on the AMSR-E LWP retrieval based on microwave emission rather than the higher resolution MODIS LWP retrieval based on visible and near-infrared reflectance because of a systematic bias in the MODIS LWP for cases where absorbing aerosol is present above the cloud (Haywood et al., 2004; Wilcox et al., 2009).

The satellite data are obtained for the oceanic region offshore of southern Africa bounded by $10^{\circ} \mathrm{W}$ to $15^{\circ} \mathrm{E}$ longitude and $20^{\circ} \mathrm{S}$ to $0^{\circ} \mathrm{S}$ latitude during July, August, and September (JAS). Aerosols emanating from the burning of the African savannah are clearly evident over this region of ocean in satellite imagery (Fig. 1a). All satellite data, with the exception of the CALIPSO data, are analyzed for the JAS period during 2005 and 2006. CALIPSO data are analyzed for the JAS period from 2006 through 2008. Instantaneous AMSR-E data are obtained for each orbit averaged in space on a $0.25^{\circ}$ lat.-lon. grid. Level-2 AIRS pixel data are obtained at $45 \mathrm{~km}$ resolution, which is a broader spatial resolution than the grid. AIRS samples are colocated with the other data sets by obtaining the AIRS sample nearest the center point of the $0.25^{\circ}$ grid cell. AIRS provides valid temperature 
Table 1. Data sources.

\begin{tabular}{llllll}
\hline Parameter & Sensor & Platform & Product & Units & RMS uncertainty \\
\hline aerosol/cloud feature & CALIOP & CALIPSO & L2 VFM V3 & $\mathrm{n} / \mathrm{a}$ & $\mathrm{n} / \mathrm{a}$ \\
Aerosol index & OMI & Aura & L2G-OMAERUVG v.2 & $\mathrm{n} / \mathrm{a}$ & $\mathrm{n} / \mathrm{a}$ \\
SST & AMSR-E & Aqua & REMSS v.5 & $\mathrm{K}$ & $0.76 \mathrm{~K}^{*}$ \\
LWP & AMSR-E & Aqua & REMSS v.5 & $\mathrm{g} \mathrm{m}^{-2}$ & $25 \mathrm{~g} \mathrm{~m}^{-2 *}$ \\
Air temperature & AIRS & Aqua & RetStd, v.5 & $\mathrm{K}$ & $1.5 \mathrm{~K}^{* * *}$ \\
Cloud cover & MODIS & Aqua & MYD06, col. 5 & $\mathrm{n} / \mathrm{a}$ & $\mathrm{n} / \mathrm{a}$ \\
\hline
\end{tabular}

Estimated uncertainties are reported RMS error of retrieved parameter at instrument resolution. * Wentz et al. (2003); ** Wentz (1997); ${ }^{* * *}$ Susskind et al. (2007).
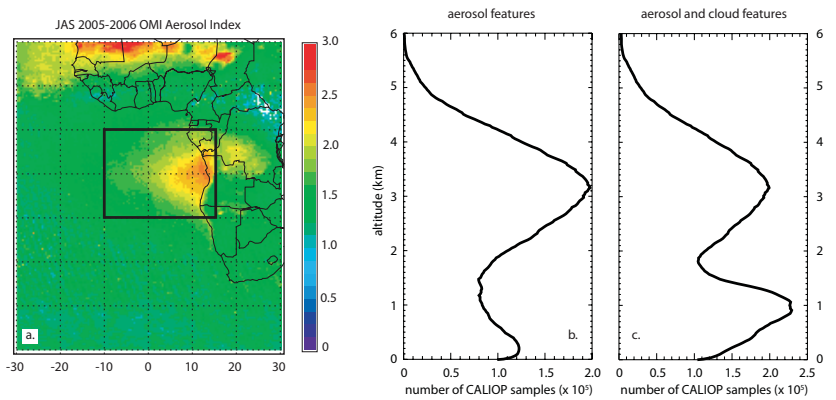

Fig. 1. (a) 2005-2006 July, August, and September average OMI aerosol index (from: Wilcox et al., 2009). (b) Vertical distribution of aerosol features, and (c) vertical distribution of aerosol and cloud features. Aerosol and cloud features are obtained from the CALIPSO feature mask product for July, August, and September 2006-2008.

retrievals even up to $90 \%$ cloud cover (Susskind et al., 2006). Many $0.25^{\circ}$ grid cells confidently identified as overcast are collocated with valid AIRS retrievals. This indicates that for many cases some clear-sky regions are adjacent to the overcast grid cell, yet within the broader AIRS footprint. Level-2 MODIS cloud pixel data (Platnick et al., 2003) are obtained at $1 \mathrm{~km}$ resolution and used to screen for overcast conditions as described below.

The AMSR-E gridded LWP is an average over the entire $0.25^{\circ}$ area, including clear-sky portions of the grid cell. Therefore, the overcast LWP can only be obtained for grid cells confidently determined to be overcast. Because cloud thickening will be diagnosed by changes in LWP, and differences in LWP between broken cloud scenes can occur either because of differences in the thickness of the cloud layer or differences in cloud fraction, a stringent test for overcast conditions is made to isolate the thickening effect. Except where noted, only overcast grid cells are used in the analysis. This overcast screening is the same as applied operationally in the level-2 1-km MODIS visible/near-infrared cloud optical thickness and cloud drop effective radius product (Platnick et al., 2003). In practice, the overcast screening is applied by only using grid cells completely spanned by MODIS 1- $\mathrm{km}$ footprints with valid retrievals of cloud optical thickness and cloud drop effective radius flagged as "confident". This conservative screening for overcast conditions captures only about $30 \%$ of the overall cloud cover because many clouds are smaller than a grid cell. However, there remain greater than 47000 overcast grid cells with valid coincident SST, LWP, and OMI AI values in two years of daytime satellite overpasses during the JAS period.

The OMI AI is used to estimate the column amount of smoke residing above the cloud. The OMI AI increases with the amount of smoke residing in the column and may be retrieved even for overcast conditions (Hsu et al., 1996; Torres et al., 2007). OMI AI is zero in the absence of aerosols and increases approximately linearly with the UV absorption optical depth. OMI AI values within the domain of interest vary from -1.5 to 3.5 where values less than zero may indicate the presence of scattering aerosols and the positive values indicate the presence of absorbing aerosols. In addition to the optical thickness of aerosols, the magnitude of the AI also depends on the optical properties and vertical distribution of the aerosols. Having little knowledge of the variability of aerosol optical properties in our study, it is not possible to quantitatively assess the uncertainties related to this variability in our application of the AI data. Variations in the vertical distribution of aerosols, however, is not a likely source of significant error in using the OMI AI as a proxy for smoke loading above clouds. Torres et al. (1998) find that variations in the altitude of absorbing aerosol over a range of approximately $5 \mathrm{~km}$ have little impact on ultraviolet radiance for cases with a surface reflectance of 0.6 , a value consistent with measured UV reflectance for liquid water clouds (Eck et al., 1987).

A summary of observing systems used in this study appears in Table 1, including values of reported uncertainties in instantaneous parameter retrievals from the literature estimated from the RMS error of retrievals performed at instrument resolution. 


\section{The radiative effect of smoke aerosol}

Smoke aerosols from African savannah burning directly heat the atmospheric layer in which they reside owing to absorption of solar radiation (Pilewskie et al., 2003; Magi et al., 2008). Calculations with the plane-parallel radiative transfer model of Chou (1992) are performed in order to illustrate the radiative consequences of a thick layer of absorbing aerosol overlaying a low cloud deck. Of particular interest are the vertical distribution of the aerosol in relation to the cloud-topped boundary layer, and the resulting vertical profile of atmospheric heating. Profiles of aerosol and cloud features, determined statistically from the CALIPSO satellite measurements, are used to constrain the radiative transfer calculations and determine where in the column to expect the thermal signature of the aerosol radiative warming.

In the lower troposphere the CALIOP lidar identifies aerosol and cloud features at $30 \mathrm{~m}$ vertical resolution and $333 \mathrm{~m}$ horizontal resolution. The vertical number distribution of all daytime aerosol features identified during the JAS period from 2006 through 2008 is shown in Fig. 1b. All daytime CALIPSO passes through the box shown in Fig. 1a are accumulated in the profile shown in Fig. 1b and c. Although the sensitivity of CALIOP to detecting aerosol and cloud features is weaker for the daylight portions of CALIPSO orbits (Winker et al., 2009), only daytime passes are used here in order to determine the smoke profile when solar absorption is occurring. The presence of aerosol features clearly peaks between 2 and $4 \mathrm{~km}$, indicating that the smoke is preferentially transported from the continent to the southeastern Atlantic ocean in plumes between those altitudes. Aerosol features in the boundary layer are substantially smaller in number than at $3 \mathrm{~km}$.

The number distribution of all aerosol and cloud features is shown in Fig. 1c. The stratocumulus clouds occur predominantly between 0.5 and $1.3 \mathrm{~km}$. A distinct minimum in aerosol and cloud features occurs between the stratocumulus cloud layer and the elevated smoke aerosol layer. Based on these results, a representative profile with a single layer of elevated absorbing aerosols and single layer of shallow clouds below is imposed in the radiative transfer model (Fig. 2).

The model simulates scattering and absorption of shortwave radiation in a single column by aerosols, clouds, ozone, water vapor, oxygen, and carbon dioxide in 75 pressure levels from the surface to the top of the atmosphere. Each layer is approximately $24 \mathrm{hPa}$ thick in the lower and middle troposphere. The vertical distribution of AOD in each model layer is shown in Fig. 2a for the case of total column optical thickness of value 1 . The aerosols are distributed in a half-sinusoidal profile from 1.5 to $4.2 \mathrm{~km}$ altitude with peak aerosol concentration at about $3 \mathrm{~km}$ altitude. Aerosol optical properties are derived from in-situ observations during the SAFARI 2000 field campaign (Haywood et al., 2003) where it is reported that the single-scatter albedo was 0.89 at $0.55 \mu \mathrm{m}$. A spectral dependence of the single-scatter albedo
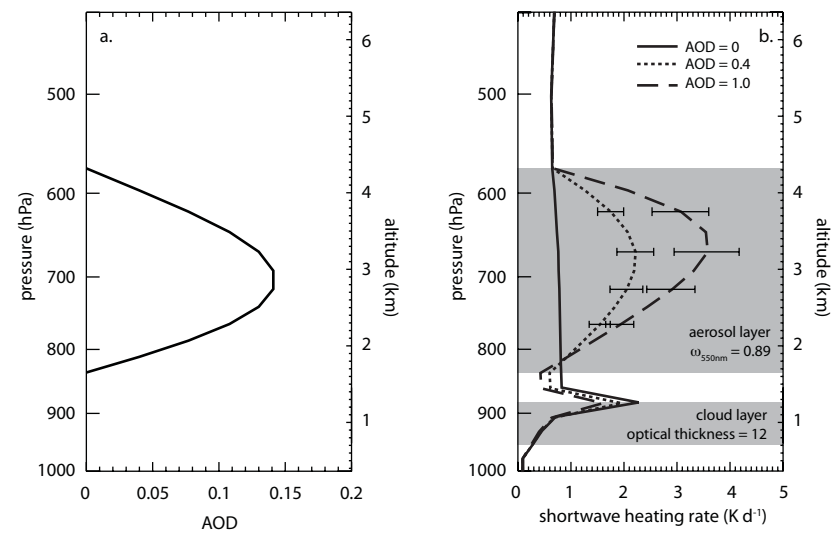

Fig. 2. (a) The vertical profile of aerosol optical depth (AOD) in each $24 \mathrm{hPa}$ layer of the radiative transfer model for the case with total column optical depth of 1.0. (b) Simulated atmospheric shortwave heating rates for smoke layers of $\mathrm{AOD}=0,0.4$, and 1.0 above a stratocumumlus cloud layer of optical thickness 12 and aerosol single-scattering albedo at $550 \mathrm{~nm}$ of 0.89 . Horizontal bars indicate the range of heating rates for single-scattering albedo $0.89 \pm 0.03$.

of $-0.1 \mu \mathrm{m}^{-1}$ is used to extrapolate the $0.55 \mu \mathrm{m}$ value to other wavelengths for the broadband radiative transfer calculations based on the column-integrated surface sun photometer measurements also made during SAFARI 2000 (Eck et al., 2003). Simulated clouds are in a single layer from 0.5 to $1.25 \mathrm{~km}$ altitude with uniform liquid water mixing ratio of $0.07 \mathrm{~g} \mathrm{~kg}^{-1}$ yielding a cloud of total optical thickness of 12 .

The diurnal mean shortwave radiative heating rate profile is shown in Fig. $2 b$ for cases of AOD equal to 0, 0.4, and 1.0 and cloud fraction of 1 . In the absence of smoke aerosol the lower tropospheric shortwave heating rate is about $1 \mathrm{Kd}^{-1}$. The radiative heating rate peaks between the 600 and $700 \mathrm{hPa}$ pressure levels for smoke and cloud profiles constrained by CALIPSO observations. The peak heating rate in the aerosol layer is $2 \mathrm{~K} \mathrm{~d}^{-1}$ and $3.5 \mathrm{~K} \mathrm{~d}^{-1}$ for AOD of 0.4 and 1.0 respectively. Seasonal-mean AOD values for cloudy conditions over the southeast Atlantic Ocean are presented by Chand et al. (2009). The mean value reaches as high as 0.5 near the coast and instantaneous values can reach as high as 1.0 (see Chand et al., 2009, Supplement Fig. 2). Measures of the single-scatter albedo are variable and uncertain. Allowing for a range of $+/-0.03$ in the single-scatter albedo yields a range of $+/-0.5 \mathrm{~K} \mathrm{~d}^{-1}$ in the heating rate at the altitude of peak heating. This range in single-scatter albedo is consistent with estimates of measurement uncertainties in singlescatter albedo and is greater than the range of average values reported for different flights during the SAFARI $2000 \mathrm{cam}$ paign (Haywood et al., 2003).

The difference between the solid line in Fig. $2 b$ and the other lines is the shortwave heating rate attributable to aerosol absorption. The aerosol shortwave heating rate for cloud-free conditions and averaged over the aerosol layer is 


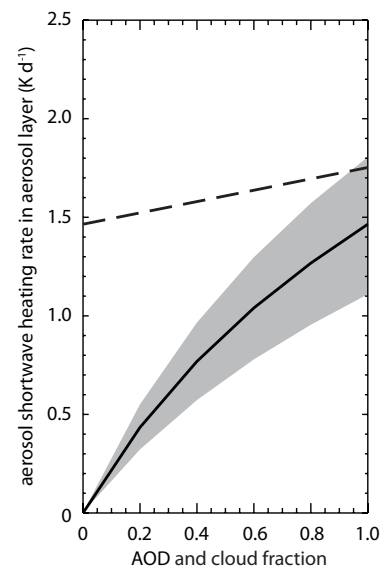

Fig. 3. Atmospheric shortwave heating rate averaged over the simulated smoke layer (1700-4300 m). Heating rate vs. AOD for cloudfree conditions indicated by the solid line and the dashed line shows the heating rate for $\mathrm{AOD}=1.0 \mathrm{vs}$. fraction of cloud cover beneath the smoke layer. Gray region shows range of heating rate for singlescattering albedo $0.89 \pm 0.03$.

shown as a function of AOD from 0 to 1 in Fig. 3 (solid line). The layer-mean aerosol heating rate increases from 0 for no aerosol to just less than $1.5 \mathrm{~K} \mathrm{~d}^{-1}$ for $\mathrm{AOD}=1$. The aerosol shortwave heating rate increases with cloud fraction because the smoke aerosol absorbs both the downwelling solar radiation and the upwelling solar radiation reflected by the cloud beneath the aerosol. For the AOD $=1$ case, the aerosol shortwave heating rate increases from just less than $1.5 \mathrm{~K} \mathrm{~d}^{-1}$ for cloud-free conditions to $1.8 \mathrm{~K} \mathrm{~d}^{-1}$ for overcast conditions.

The aerosol shortwave heating rate for $\mathrm{AOD}=1$ shown in Fig. 3 corresponds to a radiative flux convergence in the atmosphere of $42 \mathrm{~W} \mathrm{~m}^{-2}$ for cloud-free conditions and $57 \mathrm{~W} \mathrm{~m}^{-2}$ for overcast conditions. These values can be compared with atmospheric radiative forcing efficiency values reported elsewhere in the literature. Chand et al. (2009) use Calipso retrievals of aerosol optical depth in clear and cloudy conditions together with aerosol optical properties from the SAFARI 2000 campaign and a radiative transfer model to report a clear-sky atmospheric forcing efficiency of $59 \mathrm{~W} \mathrm{~m}^{-2} \tau_{550 \mathrm{~nm}}^{-1}$ and an overcast forcing efficiency of $91 \mathrm{~W} \mathrm{~m}^{-2} \tau_{550 \mathrm{~nm}}^{-1}$. These values are greater than the estimates reported here because Chand et al. (2009) adopt a lower value of the single scattering albedo (0.85). Magi et al. (2008) report an atmospheric forcing efficiency based on a radiative transfer model and using a more rigorous application of SAFARI 2000 observations that accounts for spatio-temporal variability in aerosol radiative properties. But they compute a value only for clear-sky conditions. The Magi et al. (2008) value is $70.3+/-5.1 \mathrm{~W} \mathrm{~m}^{-2} \tau_{550 \mathrm{~nm}}^{-1}$. They observed a negative correlation between aerosol single-scattering albedo and AOD which would lead to an enhanced atmospheric radiative forcing efficiency that is not accounted for here or in the
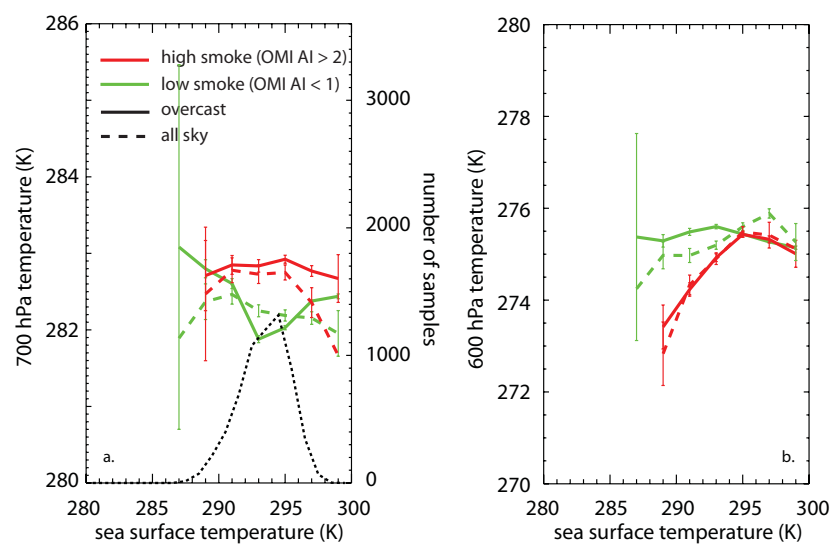

Fig. 4. AIRS atmospheric temperature at the (a) $700 \mathrm{hPa}$ pressure level and (b) $600 \mathrm{hPa}$ pressure level against AMSR-E sea surface temperature for high smoke and low smoke samples. Air temperatures are shown separately for overcast samples only (solid lines), and for all samples (dashed). Vertical bars are the estimated $95 \%$ confidence interval based on variability in each SST bin. The dotted line in (a) indicates the number distribution of SST values (scale appears on right-hand axis). 2267 samples with $\mathrm{OMI} \mathrm{AI}<1 ; 3126$ samples with $1<\mathrm{OMI} \mathrm{AI}<=2 ; 897$ samples with $\mathrm{OMI} \mathrm{AI}>2$.

Chand et al. (2009) study, and may explain the higher clearsky forcing efficiency reported in Magi et al (2008). The calculations presented in Figs. 2 and 3 were designed to explore the radiative consequences of variations in cloud cover and smoke aerosol loading for cases where smoke resides above clouds in the same column. On the basis of the comparisons with other reported values, the absolute forcing values computed here may be underestimated, but the caluculations presented here illustrate the relevant physics and capture the approximate magnitude of the variations in radiative forcing.

\section{Smoke absorption and lower tropospheric air temperature}

The AIRS air temperature retrievals at the 700 and $600 \mathrm{hPa}$ pressure levels are shown in Fig. 4 binned by AMSR-E SST. Vertical bars in Figs. 4 and 5 indicate the 95\% confidence interval estimated as plus/minus double the standard deviation of the mean of all samples in each SST bin. In the absence of reliable boundary layer air temperature, SST is used here as general indicator of boundary layer temperature. While LWP increases strongly with SST in this region, as discussed further below, there is no apparent relationship between free-tropospheric temperature above the boundary layer and SST. The data are further stratified by low smoke loading and high smoke loading conditions, where low smoke conditions are indicated by OMI AI less than 1 and high smoke conditions are indicated by OMI AI greater than 2. At the $700 \mathrm{hPa}$ pressure level, approximately the level of peak aerosol shortwave radiative heating, high smoke 

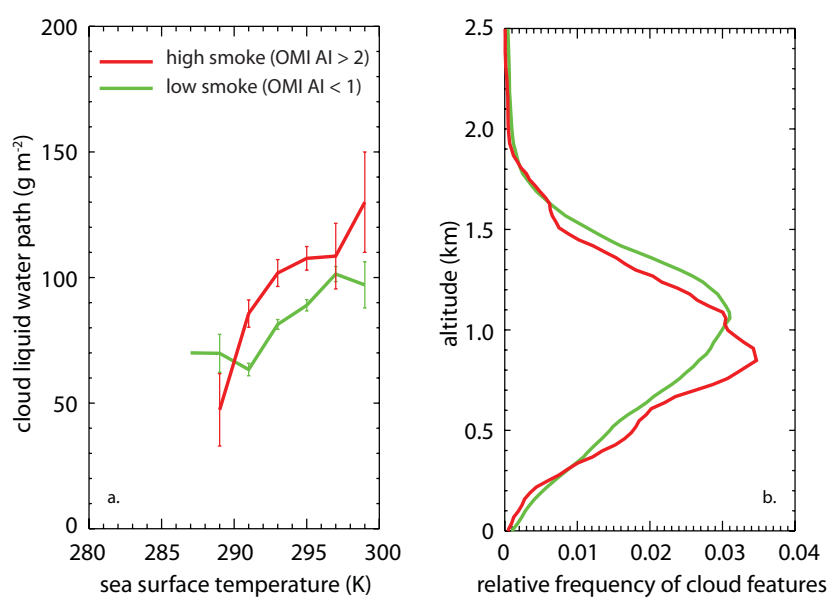

Fig. 5. (a) AMSR-E cloud liquid water path against AMSR-E sea surface temperature and (b) relative frequency of occurrence of CALIPSO cloud features. Both are shown separately for high smoke (red) and low smoke (green) samples. Vertical bars in (a) are the estimated $95 \%$ confidence interval based on variability in each SST bin. The total number of low smoke and high smoke CALIPSO cloud features between 0 and $2.5 \mathrm{~km}$ altitude are 3279831 and 922,596 respectively.

samples are systematically warmer than low smoke samples by nearly $1 \mathrm{~K}$. This is true regardless of SST except for those samples at the edges of the SST distribution. However, less than $8 \%$ of samples are associated with SST less than $290 \mathrm{~K}$ or greater than $298 \mathrm{~K}$ (SST distribution is indicated by dotted line in Fig. 4a). The cloud LWP data discussed below is limited only to overcast samples. The AIRS retrievals, however, are available for conditions that are either clear or overcast at the $0.25^{\circ}$ grid resolution. Figure 4 indicates that the high smoke loading scenes are warmer at $700 \mathrm{hPa}$ than the low smoke scenes regardless of cloud cover.

The threshold on OMI AI of greater than 2 to indicate high smoke loading is chosen to isolate samples that are unambiguously overlain by a significant amount of absorbing aerosol. The threshold on AI of less than 1 for low smoke cases is chosen to isolate samples with unambiguously less absorbing aerosol above the cloud layer. This population of samples may include cases with scattering (high single scatter albedo) aerosols above cloud. The gap in OMI AI between the two populations allows for some noise in the measurement as well as the other sources of uncertainty discussed in Sect. 2 above. The results in this section and Sect. 5 below are qualitatively robust to reducing the thresholds by 1 or using a single threshold of either 0 or 1 to discriminate between the two populations.

Estimates of heating rates by dynamical processes at $700 \mathrm{hPa}$ are found to be substantially smaller than the aerosol shortwave heating rates estimated above. Horizontal temperature advection and subsidence heating are derived using the temperature and wind fields from the NCEP reanalysis data
(Kalnay et al., 1996) for low smoke loading and high smoke loading samples (not shown). The sum of the differences between low smoke and high smoke conditions for the components of dynamical heating are less than $0.5 \mathrm{Kd}^{-1}$, suggesting that much of the difference in AIRS temperatures at this level between low smoke and high smoke conditions is attributable to the shortwave radiative heating.

At the $600 \mathrm{hPa}$ pressure level, near the top of the smoke layer, there is no systematic difference between low smoke loading and high smoke scenes, except for the $30 \%$ of samples with SST cooler than $293 \mathrm{~K}$, where the low smoke samples are on average warmer than the high smoke samples. As indicated in Fig. 2, the aerosol heating rates at the $600 \mathrm{hPa}$ level are substantially smaller than at the heating rates at the $700 \mathrm{hPa}$ level, therefore shortwave aerosol radiative effects are expected to contribute only a small, if any, difference in temperature between low OMI AI and high OMI AI samples at the $600 \mathrm{hPa}$ level. Furthermore, the free troposphere is decoupled from the boundary layer, therefore SSTs are not expected to contribute to any difference in temperatures between low OMI AI and high OMI AI samples.

\section{Lower tropospheric warming and cloud thickening}

Cloud LWP increases strongly with SST as shown in Fig. 5a. In the southern half of the domain the mean overcast LWP and mean SST both increase to the northwest. In the northern half of the domain the spatial patterns of the mean fields are not coherent. The positive correlation may suggest that higher SSTs promote thicker clouds through greater fluxes of heat and moisture from the surface to the boundary layer. This characterizes the response of clouds to changes of SST on short time scales of a day or less (Pincus et al., 1997). But given the non-local effects of SSTs and static stability upwind on local cloud development (Klein et al., 1995), proper characterization of the relationship between SST and LWP requires a Lagrangian analysis. Nevertheless, regardless of the SST, Fig. 5a indicates that LWP is systematically greater by approximately $20 \mathrm{~g} \mathrm{~m}^{-2}$ for overcast scenes overlain by high levels of smoke loading compared to low smoke loading scenes. These results are consistent with the large-eddy simulation results presented by Johnson et al. (2004) where simulations of a stratocumulus cloud layer overlain by a layer of absorbing biomass burning aerosol resulted in LWP values of 5 to $10 \mathrm{~g} \mathrm{~m}^{-2}$ greater than in a simulation without the biomass burning aerosol layer.

The Johnson et al. (2004) simulations indicate that the increase in the buoyancy of the layer immediately above the cloud owing to warming by solar absorption reduces cloudtop entrainment. Reduced entrainment of dry air through the cloud-top acts to preserve humidity and cloud cover in the boundary layer. The result is a shallower boundary layer with greater LWP in the cloud layer. 
The shallower boundary layer is indicated in the frequency of occurrence of CALIPSO cloud features sorted by OMI AI (Fig. 5b). The relative frequency of occurrence of cloud features for high smoke and low smoke conditions is shown separately as the ratio of the number of features in each $30 \mathrm{~m}$ layer in the CALIPSO lower-tropospheric feature mask product and the total number of either high-smoke or low-smoke features detected below $2.5 \mathrm{~km}$ altitude. The vertical distribution of cloud features is lower for the high-smoke cases compared to the low-smoke cases. The altitude of the peak of the cloud feature distribution is lower by as much as $200 \mathrm{~m}$ for the high-smoke cases compared to the low smoke cases. Subsidence of the cloud deck accompanies subsidence of the free-troposphere above. The altitude of the cloud top is determined by a balance between the subsidence above the boundary layer and the vertical entrainment at cloud-top. With the reduction in entrainment implied by the warmer freetropospheric air above the inversion when smoke is present, subsidence of the cloud-top accompanies the continued subsidence in the free-troposphere above. The subsidence of the cloud-top is also indicated in greater cloud-top pressure and greater cloud-top temperature values in the MODIS data for high smoke conditions for all values of SST. However, these values are determined from a combination of the observed infrared radiances and simulated temperature profiles from an atmospheric analysis data product which has known deficiencies in resolving strong temperature inversions (Harshvardhan et al., 2009), therefore the MODIS products may not reliably capture the magnitude of cloud-top subsidence in this region of strong inversions above the boundary layer. Indeed, the difference in cloud-top pressure between high-smoke and low-smoke conditions implied by MODIS is substantially greater in magnitude than is indicated in the CALIPSO data.

Increases in LWP associated with increases in aerosol load are often attributed to a microphysical interaction whereby aerosols entrained into the cloud layer suppress drizzle (Albrecht 1989). Often this effect is argued to yield an increase in area-averaged LWP through an increase in cloud cover. Only overcast LWP is addressed in the present study. Hence, the increase in LWP attributed here to the smoke aerosol is a geometric thickening or an increase in the liquid water content of the cloud. A significant microphysical response of the clouds to the smoke is not expected based on the CALIPSO analysis presented above and the SAFARI 2000 results (e.g. Hobbs 2002) indicating clear air often occurs beneath the smoke layers. This is further confirmed by Costantino and Bréon (2010) who find that $83 \%$ of CALIPSO profiles, out of more than 7000 examined in the same region, have a vertical profile where the aerosol and cloud layers are separated by at least $250 \mathrm{~m}$. If substantial microphysical interactions between the smoke layer and cloud layer are occurring then a negative correlation between aerosol load and cloud drop effective radius would be expected. Examination of the MODIS data indicates that the effective cloud drop radius retrieved for the high smoke cases is smaller than that of the low smoke cases by approximately $1 \mu \mathrm{m}$. However, the radiative impact of the smoke above the cloud introduces a low bias of less than $2 \mu \mathrm{m}$ in the MODIS retrievals of effective radius (Haywood et al., 2004), which could account for the difference observed here. Costantino and Bréon (2010) confirm that the inverse relationship between cloud drop effective radius with aerosol load in satellite data is substantially weaker for cases where the smoke and cloud layers are physically separated compared to cases where the vertical separation is small and microphysical interaction is likely. These results suggest that the increase in LWP observed in this study is more likely a response to the warming above the cloud layer than a microphysical interaction of aerosol entrained into the cloud.

A layer of absorbing aerosol over a bright cloud layer will darken the scene as viewed from above owing to the absorption of both downwelling solar radiation and upwelling reflected solar radiation. Podgorny and Ramanathan (2001) use radiative transfer modeling to describe how the direct radiative forcing of scenes containing both absorbing aerosols and low clouds depends upon cloud fraction. They find that the direct aerosol radiative forcing at the top-of-atmosphere changes from negative to positive as cloud cover increases. The level of cloud cover corresponding to the change in sign of the forcing depends on the aerosol optical thickness, aerosol single-scattering albedo, and whether the aerosol layer resides above the cloud or in the cloud. Chand et al. (2009) determine that this critical cloud fraction is about 0.4 for the southeast Atlantic region considered here based on satellite remote sensing observations. Therefore, the direct radiative forcing at the top-of-atmosphere of the smoke aerosol is expected to be positive for the overcast scenes explored here. However, the albedo of low clouds increases with LWP, therefore the thickening of the stratocumulus cloud in response to overlaying smoke aerosol is expected to yield a negative semi-direct radiative forcing that counteracts the positive aerosol direct radiative forcing. In the Johnson et al. (2004) simulations of the case of absorbing aerosol over cloud these two forcing effects nearly cancel. As noted above, however, this balance will depend on the amount and optical properties of both the aerosols and the cloud. Therefore, the cancelation of the two forcing effects should not be expected to hold for all cases of aerosol over low clouds.

This study has focused specifically on the increase of overcast LWP attributable to aerosol direct heating above the cloud. Increased stability of the lower troposphere may also increase the coverage (i.e. cloud fraction) of stratocumulus cloud as implied by the spatio-temporal correlation of lower tropospheric static stability and cloud cover (Klein and Hartmann, 1993). This effect would contribute an additional negative radiative forcing. 


\section{Summary}

The stratocumulus clouds capping the marine boundary layer over the Southeast Atlantic Ocean frequently reside below an elevated layer of smoke aerosol transported offshore from the regions of African Savannah burning. This study has investigated the radiative impact of the smoke on the atmospheric temperature in the free-troposphere above the marine boundary layer, and the properties of overcast samples of the clouds capping the marine boundary layer.

Analysis of CALIPSO satellite lidar data indicate that the smoke over the ocean primarily resides between $2 \mathrm{~km}$ and $4 \mathrm{~km}$ altitude, while the stratocumulus cloud decks generally reside below $1.5 \mathrm{~km}$ altitude. Radiative transfer calculations based on the observed profile and aerosols and clouds, as well as aerosol optical properties available from the literature show that the presence of the smoke layer leads to a broad layer of heating the lower troposphere that peaks near the $700 \mathrm{hPa}$ pressure level. Mean shortwave radiative heating in the aerosol layer for cloud-free conditions exceeds $1 \mathrm{~K} \mathrm{~d}^{-1}$ for AOD values greater than about 0.5 and exceeds $1.5 \mathrm{~K} \mathrm{~d}^{-1}$ for AOD of 1. A small enhancement of the layer-mean heating rate occurs when clouds are present beneath the smoke owing to the additional upwelling component of solar radiation reflected from the cloud-top. The heating rate in the smoke layer may vary by as much as $+/-0.5 \mathrm{~K} \mathrm{~d}^{-1}$ within the range of observed values of the single-scatter albedo and allowing for measurement uncertainties in that quantity.

AIRS satellite retrievals of atmospheric temperature indicate that the temperature at $700 \mathrm{hPa}$ is warmer by nearly $1 \mathrm{~K}$ for cases where smoke is present above the cloud compared to cases with little or no smoke above the cloud. Differences in the dynamical heating rates estimated from NCEP reanalysis between high-smoke and low-smoke conditions are considerably smaller than the aerosol radiative heating rates estimated above, indicating that the aerosols are more important than dynamics for modifying the temperature above the cloud-top inversion. The warm conditions above the cloud layer coincide with LWP values for overcast conditions that are greater for high-smoke cases by more than $20 \mathrm{~g} \mathrm{~m}^{-2}$ compared to low smoke or smoke-free cases, and the vertical distribution of cloud features in the Calipso data peaks at an altitude that is as much as $200 \mathrm{~m}$ lower for the high-smoke cases. The smoke layer is typically separated vertically from the cloud layer; hence little evidence is found for microphysical interactions between the smoke particles and the cloud layer. Therefore the thickening and subsidence of the cloud layer are attributed to the warming above the cloud-top. Warming in this layer increases the buoyancy of the free-tropospheric air above the cloud and inhibits entrainment of that air into the cloud layer. As indicated by cloud modeling studies, reduced drying of the boundary layer by cloud-top entrainment enhances LWP in the cloud and promotes subsidence of the cloud-top. The satellite data presented in this study indicate that this semi-direct thickening of cloud in response to the ra- diative effects of absorbing smoke aerosols is occurring during the dry season over the Southeast Atlantic Ocean.

The direct radiative effect of absorbing aerosols residing over a bright cloud deck is a positive radiative forcing (warming) at the top of the atmosphere. However, the semi-direct thickening of the cloud layer is a negative radiative forcing (cooling) owing to the enhanced albedo of thicker clouds. The balance of these opposing radiative forcing effects will depend on the amount and optical properties of the aerosol, as well as the optical thickness and fractional coverage of the cloud deck.

Acknowledgements. This work was supported by the NASA Radiation Sciences Program and NASA grant \# NNX10AM44G. AMSR-E data are produced by Remote Sensing Systems and sponsored by the NASA Earth Science REASoN DISCOVER Project and the AMSR-E Science Team. These data are available at www.remss.com. OMI and AIRS data are distributed by the Goddard Earth Sciences Data and Information Services Center. MODIS atmosphere products are distributed by the MODIS Adaptive Processing System at NASA GSFC. CALIPSO data are distributed by the Atmospheric Science Data Center at NASA Langley. I thank the two anonymous reviewers for their comments on the discussion paper that preceded this paper.

Edited by: P. Stier

\section{References}

Ackerman, A. S., Toon, O. B., Stevens, D. E., Heymsfield, A. J., Ramanathan, V., and Welton, E. J.: Reduction of tropical cloudiness by soot, Science, 288, 1042-1047, 2000.

Albrecht, B. A.: Aerosols, Cloud Microphysics, and Fractional Cloudiness, Science, 245, 1227-1230, 1989.

Brioude, J., Cooper, O. R., Feingold, G., Trainer, M., Freitas, S. R., Kowal, D., Ayers, J.K., Prins, E., Minnis, P., McKeen, S. A., Frost, G. J., and Hsie, E.-Y.: Effect of biomass burning on marine stratocumulus clouds off the California coast, Atmos. Chem. Phys., 9, 8841-8856, doi:10.5194/acp-9-8841-2009, 2009.

Chand, D., Wood, R., Anderson, T. L., Satheesh, S. K., and Charlson, R. J.: Satellite-derived direct radiative effect of aerosols dependent on cloud cover, Nat. Geosci., 2, 181-184, 2009.

Chou, M. D.: A solar radiation model for use in climate studies, J. Atmos. Sci., 49, 762-772, 1992.

Costantino, L. and Bréon, F.-M.: Analysis of aerosol-cloud interaction from multi-sensor satellite observations, Geophys. Res. Lett., 37, L11801, doi:10.1029/2009GL041828, 2010.

Eck, T. F., Bhartia, P. K., Hwang, P. H., and Stowe, L. L.: Reflectivity of Earth's surface and clouds in ultraviolet from satellite observations, J. Geophys. Res., 92, 4287-4296, 1987.

Eck, T. F., Holben, B. N., Ward, D. E., Mukelabai, M. M., Dubovik, O., Smirnov, A., Schafer, J. S., Hsu, N. C., Piketh, S. J., Queface, A., Le Roux, J., Swap, R. J., and Slutsker, I.: Variability of biomass burning aerosol optical characteristics in southern Africa during the SAFARI 2000 dry season campaign and a comparison of single scattering albedo estimates from radiometric measurements, J. Geophys. Res., 108(D13), 8477, doi:10.1029/2002JD002321, 2003. 
Harshvardhan, Zhao, G., Di Girolamo, L., and Green, R. N.: Satellite-observed location of stratocumulus cloud-top heights in the presence of strong inversions, IEEE Trans. Geosci. Remote Sens., 47, 1421-1428, 2009.

Hansen, J., Sato, M., and Ruedy, R.: Radiative forcing and climate response. J. Geophys. Res., 102, 6831-6864, 1997.

Haywood, J. M., Francis, P., Dubovik, O., Glew, M., and Holben, B.: Comparison of aerosol size distributions, radiative properties, and optical depths determined by aircraft observations and Sun photometers during SAFARI 2000, J. Geophys. Res., 108, 8471, doi:10.1029/2002JD002250, 2003.

Haywood, J. M., Osborne, S. R., and S. J. Abel: The effect of overlying absorbing aerosol layers on remote sensing retrievals of cloud effective radius and cloud optical depth, Q. J. Roy. Meteorol. Soc., 130, 779-800, 2004.

Herman, J. R., Bhartia, P. K., Torres, O., Hsu, C., Seftor, C., and Celarier, E.: Global distribution of UV-absorbing aerosols from Nimbus 7/TOMS data, J. Geophys. Res., 102, 16911-16922, 1997.

Hobbs, P. V.: Clean air slots amid atmospheric pollution, Nature, 415, p. 861, 2002.

Johnson, B. T., Shine, K. P., and Forster, P. M.: The semi-direct aerosol effect: Impact of absorbing aerosols on marine stratocumulus, Q. J. R. Meteorol. Soc., 130, 1407-1422, 2004.

Hsu, N. C., Herman, J. R., Bhartia, P. K., Seftor, C. J., Torres, O., Thompson, A. M., Gleason, J. F., Eck, T. F., and Holben, B. N.: Detection of biomass burning smoke from TOMS measurements. Geophys. Res. Lett., 23, 745-748, 1996.

Klein, S. A. and Hartmann, D. L.: The seasonal cycle of low stratiform clouds, J. Climate, 6, 1587-1606, 1993.

Klein, S. A, D. L. Hartmann, and J. R. Norris: On the relationships among low-cloud structure, sea surface temperature, and atmospheric circulation in the summertime northeast Pacific, J. Climate, 8, 1140-1155, 1995.

Liepert, B., Feichter, J., Lohmann, U., and Roeckner, E.: Can aerosols spin down the water cycle in a warmer and moister world?, Geophys. Res. Lett., 31, L06207, doi:10.1029/2003GL019060, 2004.

Liu, Z., Vaughan, M., Winker, D., Kittaka, C., Getzewich, B., Kuehn, R., Omar, A., Powell, K., Trepte, C., and Hostetler, C.: The CALIPSO lidar cloud and aerosol discrimination: Version 2 algorithm and initial assessment of performance, J. Atmos. Ocean. Technol., 26, 1198-1213, 2009.

Magi, B. I., Fu, Q., Redemann, J., and Schmid, B.: Using aircraft measurements to estimate the magnitude and uncertainty of the shortwave direct radiative forcing of southern African biomass burning aerosol, J. Geophys. Res., 113, D05213, doi:10.1029/2007JD009258, 2008.

McGill, M. J., Hlavka, D. L., Hart, W. D., Welton, E. J., and Campbell, J. R.: Airborne lidar measurements of aerosol optical properties during SAFARI-2000, J. Geophys. Res., 108, 8493, doi:10.1029/2002JD002370, 2003.

Pilewskie, P., Pommier, J., Bergstrom, R., Gore, W., Howard, S., Rabbette, M., Schmid, B., Hobbs, P. V., and Tsay, S. C.: Solar spectral radiative forcing during the Southern African Regional Science Initiative, J. Geophys. Res., 108, 8486, doi:10.1029/2002JD002411, 2003.
Pincus, R., Baker, M. B., and Bretherton, C. S.: What controls stratocumulus radiative properties? Lagrangian observations of cloud evolution, J. Atmos. Sci., 54, 2215-2236, 1997.

Platnick, S., King, M. D., Ackerman, A., Menzel, W. P., Baum, B. A., Riédi, J. C., and Frey, R. A.: The MODIS cloud products: Algorithms and examples from Terra, IEEE Trans. Geosci. Remote Sens., 41, 459-473, 2003.

Podgorny, I. A. and Ramanathan, V.: A modeling study of the direct effect of aerosols over the tropical Indian Ocean, J. Geophys. Res., 106, 24097-24105, 2001.

Ramanathan, V., Crutzen, P. J., Kiehl, J. T., and Rosenfeld, D.: Aerosols, climate, and the hydrological cycle, Science, 294, 2119-2124, 2001

Susskind, J., Barnet, C., Blaisdell, J., Iredell, L., Keita, F., Kouvaris, L., Molnar, G., and Chahine, M.: Accuracy of geophysical parameters derived from Atmospheric Infrared Sounder/Advanced Microwave Sounding Unit as a function of fractional cloud cover, J. Geophys. Res., 111, D09S17, doi:10.1029/2005JD006272, 2006.

Torres, O., Bhartia, P. K., Herman, J. R., Ahmad, Z., and Gleason, J.: Derivation of aerosol properties from satellite measurements of backscattered ultraviolet radiation: Theoretical basis, J. Geophys. Res., 103, 17099-17110, 1998.

Torres, O., Tanskanen, A., Veihelmann, B., Ahn, C., Braak, R., Bhartia, P. K., Veefkind, P., and Levelt, P.: Aerosols and surface UV products from Ozone Monitoring Instrument observations: An overview, J. Geophys. Res., 112, D24S47, doi:10.1029/2007JD008809, 2007.

Wentz, F. J.: A well-calibrated ocean algorithm for Special Sensor Microwave/Imager, J. Geophys. Res., 102, 8703-8718, 1997.

Wentz, F. J. and Spencer, R. W.: SSM/I rain retrievals within a unified all-weather ocean algorithm, J. Atmos. Sci., 55, 1613-1627, 1998.

Wentz, F. J. and Meissner, T.: AMSR Ocean Algorithm, Version 2, report number 121599A-1, Remote Sensing Systems, Santa Rosa, CA, available online at: www.remss.com, 66 pp., 2000.

Wentz, F. J., Gentemann, C. L., and Ashcroft, P. D.: On-orbit calibration of AMSR-E and the retrieval of ocean products, paper presented at the 12th Conference on Satellite Meteorology and Oceanography, Am. Meteorol. Soc., Long Beach, CA, USA, available online at: www.remss.com, 2003.

Wilcox, E. M., Roberts, G., and Ramanathan, V.: Influence of aerosols on the shortwave cloud radiative forcing from north Pacific Oceanic Clouds: Results from the Cloud Indirect Forcing Experiment (CIFEX), Geophys. Res. Lett., 33, L21804, doi:10.1029/2006GL027150, 2006.

Wilcox, E. M., Harshvardhan, and Platnick, S.: Estimate of the impact of absorbing aerosol over cloud on the MODIS retrievals of cloud optical thickness and effective radius using two independent retrievals of liquid water path, J. Geophys. Res., 114, D05210, doi:10.1029/2008JD010589, 2009.

Winker, D. M., Vaughan, M. A., Omar, A., Hu, Y., Powell, K. A., Liu, Z., Hunt, W. H., and Young, S. A.: Overview of the CALIPSO Mission and CALIOP Data Processing Algorithms, J. Atmos. Ocean. Technol., 26, 2310-2323, 2009. 